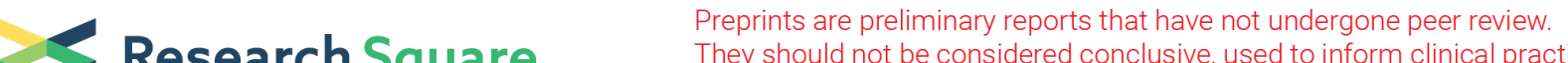 Research Square They should not be considered conclusive, used to inform clinical practice, or referenced by the media as validated information.
}

\section{Floods in Provence-Alpes-Côte D'azur and Lessons for French Flood Risk Governance}

loannis Kougkoulos ( $D$ ioannis.kougkoulos@gmail.com )

LAMSADE: Laboratoire d'analyse et modelisation de systemes pour l'aide a la decision https://orcid.org/0000-0002-5001-2961

Myriam Merad

LAMSADE: Laboratoire d'analyse et modelisation de systemes pour l'aide a la decision

Simon J. Cook

University of Dundee

loannis Andredakis

European Commission

\section{Research Article}

Keywords: France, Natural Hazards, Disaster Risk Reduction, Flood Risk Governance, Resilience, Public Policy

Posted Date: February 10th, 2021

DOI: https://doi.org/10.21203/rs.3.rs-211213/v1

License: (c) (i) This work is licensed under a Creative Commons Attribution 4.0 International License. Read Full License

Version of Record: A version of this preprint was published at Natural Hazards on July 12th, 2021. See the published version at https://doi.org/10.1007/s11069-021-04905-4. 


\section{Abstract}

France experiences catastrophic floods on a yearly basis, with significant societal impacts. In this paper, we employ a historical assessment of catastrophic past flood events in the Provence-Alpes-Côte d'Azur (PACA) region and perform Strengths-Weaknesses-Opportunities-Threats (SWOT)-analysis to evaluate some aspects of the French Flood Risk Governance (FRG) system and suggest improvements. Our evaluation shows that despite persistent government efforts, the impacts of flood events in the region do not appear to have lessened over time. Identical losses in the same locations (e.g. Riou de l'Argentière watershed) can be observed after repetitive catastrophic events (e.g. 2015, 2019) triggering local inhabitant protests. To avoid future disasters, we suggest that the French FRG should benefit from the following improvements: a) regular updates of the risk prevention plans and tools; b) the adoption of a Build Back Better logic instead of promoting the reconstruction of damaged elements in the same locations; c) taking into account undeclared damages into flood risk models (and not only those declared to flood insurance); d) increased communication between the actors of the different steps of each cycle (prepare, control, organise etc.); e) increased communication between three main elements of the cycle (risk prevention, emergency management and disaster recovery); f) an approach that extends the risk analysis outside the borders of the drainage basin (to be used in combination with the current basin risk models); and g) increased participation in FRG from local population. We also briefly discuss the use operational research methods for the optimisation of the French FRG.

\section{Introduction}

Flooding is widely considered to exert the greatest societal impacts of all natural hazards (CRED-UNISDR, 2015). The total amount of damage resulting from flood disasters globally is expected to rise in the future, partly due to long-term impacts of climate change, including sea level rise (e.g. Hallegatte et al., 2013) and intensification of precipitation events (e.g. Lenderink and Van Meijgaard, 2008; Coumou and Rahmstorf, 2012), as well as socio-economic factors (e.g. Schwarze and Wagner, 2004; Jongman et al., 2014; Winsemius et al., 2016; IPCC, 2018; Luke et al., 2018; Lamond et al., 2019; Roder et al., 2019; Vedeld et al., 2016), such as expansion of urbanization (e.g. Swiss Re, 2014; Miller and Hutchins, 2017; Zhang et al., 2018; Koc and Işık, 2020). Furthermore, insured losses from natural hazards have increased globally (Bouwer, 2011; Aerts et al., 2018; Cremades et al., 2018; Kron et al., 2019) and now represent the largest proportion of insured losses among catastrophes induced by natural hazards; global costs were approximately 50 billion Euros in 2016 alone (Aerts et al., 2018). In response to this growing problem, there has been greater research involving the coupling of flood management and insurance. This has developed to focus on multiple themes including, the development of flood risk governance and management strategies (e.g. Scolobig et al., 2014; Singkran et al., 2016; Tullos et al., 2016); the role that insurance has played after specific flood events (e.g. Schwarze and Wagner, 2004; Crichton, 2008; Gallagher, 2014; Turner et al., 2014; Surminski et al., 2015); changes of individual attitudes toward risk after experiencing a flood event (e.g. Reynaud and Aubert, 2019); the role of big data in flood insurance (e.g. Wing et al., 2020); the impacts of flooding on small- and medium-sized enterprises and on the 
insurance industry itself (Clemo, 2008); and the place of Public-Private-Partnerships (PPPs) in flood insurance (Paudel, 2012; Kunreuther, 2015). Dixit et al. (2002) underlines that the vulnerability of people in risk-prone areas must be addressed by enhancing resilience capacity. Furthermore, Cremades et al. (2018) have focused on the importance of studying societal resilience to flooding over time, which could help insurers and governments to design effective multi-sectorial partnerships, thereby reducing the costs of existing and future insurance schemes and ensuring insurability. Lamond et al. (2019) discuss the desirable improvements for several sectors (e.g. access to adequate risk information, professional skills in evaluating risk, guidance on evaluation of flood risk) in order to ensure adequate consideration of risk and mitigation options. Furthermore, even though impacts from flooding are disproportionally high for the poorest and most vulnerable (see, for example, Jongman, 2018), studies show that the developed world is also under threat (Kaufmann and Wiering, 2017; Hudson et al., 2019). For example, Miller and Hutchins (2017) underline the pressing concerns and policymaker knowledge gaps that the UK is currently facing; Crichton (2008) considers the problems of flood risk management in the UK and France; and Schwarze and Wagner (2004) focus on a flood insurance framework for Germany. Moreover, several studies have dealt with the reasons that lead homeowners to decide not to purchase disaster insurance and the implications of this in risk reduction (e.g. Kousky and Cooke, 2012; Surminski et al., 2015; Surminski and Hudson, 2017; Kousky, 2018). A recent study by Paprotny et al. (2018) indicated that the total urban area exposed to flooding in Europe has increased by $1000 \%$ over the past 150 years.

France is one such EU country that faces catastrophic flood events on an annual basis (Boudou et al., 2016; Larrue et al., 2016). A potential $2^{\circ} \mathrm{C}$ increase in global temperatures would likely further exacerbate this problem by significantly increasing flood probability (Roudier et al., 2016) and severity. These events may vary from tidal floods and storm surges in the West and North of France, to flash floods in the South and fluvial floods along main rivers, as well as urban flooding in numerous cities (Larrue et al., 2016). The NatCatSERVICE (2017), which is provided by Munich Re to the European Environment Agency under institutional agreement, and which illustrates the impacts of extreme weather and climate related events in the European Economic Area (EEA) member countries (1980-2017), ranks France as having had the most flood-related fatalities (from extreme weather and climate related events) in Europe (approximately 23,500 over the 1980-2017 period), and having had the $3^{\text {rd }}$ greatest total economic losses ralted to flooding (behind Germany and Italy) and insured losses (behind Germany and the UK). Furthermore, according to Paprotny et al. 2018, while overall exposure to floods has declined in most European countries, mostly in central and northern Europe, relative exposure has increased in France and other western states (i.e. Germany, Netherlands) seemingly because of intense urbanization processes, occupying and transforming flood prone land. A number of previous studies have focused on flood hazard (e.g. Boudou et al., 2016; Montané et al., 2017; Evin et al., 2019) and flood risk (e.g. Le Coz et al., 2016; Liefferink et al., 2019; Creach et al., 2020) in France.

Research has also focused on insurance and French Flood Risk Governance (FRG) (Lumbroso et al., 2011). For example, Hudson et al. (2019) have conducted a comprehensive study of flood insurance policies in the European Union (EU). After illustrating six different insurance market structures, Hudson et 
al. (2019) performed a multi-criteria analysis to suggest what market structure each country should move towards. Their analysis indicated that, currently, France (as well as Belgium, Spain, and Romania) belongs to what is called a 'market structure of public solidarity' which is characterised by very high penetration rates (95-100\%), government support for insurers and the premiums are unconnected to levels of risk leading to higher risk sharing. Similar studies by Larrue et al. (2016) and Kaufmann and Wiering (2017) underline that, even though the state always played an important role in France, governmental authorities are increasingly considering including private actors in the flood insurance schemes.

In short, previous research has examined how the French FRG and the French insurance system are performing in comparison to other European or global systems. To our knowledge, however, no study has yet attempted to perform a historical flood analysis in a specific region in order to identify deficiencies in the FRG system. To provide an empirical framework for this analysis, we focus on the Provence-AlpesCôte d'Azur (PACA) Region in France, which has experienced an increasing number of flood disasters, such as in October 2015 were 20 people have lost their lives. Through this case study, we (a) perform a historical analysis in order to contextualise modern flood disasters in the PACA Region; (b) highlight any deficiencies of the French FRG system; and (c) perform a Strengths, Weaknesses, Opportunities, Threats (SWOT) - analysis in order to reveal the significant strengths of the system as well as any key points that need to be reviewed for the French FRG system to improve

\section{Summary Of French Flood Risk Governance}

\subsection{A brief historical overview of French flood risk regulations}

There is already a body of research focussed on French flood disaster governance issues (on a national level) (e.g. Magnan 1995; Larrue et al., 2016; Guillier, 2017; Fournier et al., 2018; Barraqué and Moatty, 2020; Fournier, 2020). Fournier et al. (2018) provide a detailed illustration of institutional and regulatory evolution of French flood risk management during the last 30 years. Here, we provide a brief summary of this evolution in order to illustrate the regulatory framework within which the case study exists (Section $3)$.

In France, flood governance has been discussed extensively and restructured since the 1980s where the Natural Disaster Compensation Scheme (CatNat) was created (Act No. 82-600 of 13 July 1982) to cover for damages resulting from natural disasters (Guillier, 2017). In 1982, the first risk maps (Plans d'Exposition aux Risques) were drafted by municipalities to control construction and reduce vulnerability (Guillier, 2017; Barraqué and Moatty, 2020). The mechanism is financed by a compulsory additional premium applied to all citizens who buy insurance to cover damage to property (e.g. home, agriculture, car, business) and this additional premium is calculated by applying a rate to the basic insurance policy premium, which is fixed by the state and is the same for all policy holders (irrespective of the level of risk they face) (Larrue et al., 2016; Guillier, 2017; Barraqué and Moatty, 2020). Moreover, the fund is triggered 
once municipalities claim to the State that they have been affected by an exceptional event and once the State acknowledges this claim. In that case, the additional premiums set aside from insurance companies are mobilised in order to cover for the damages (Barraqué and Moatty, 2020). Furthermore, insurers have the option of purchasing reinsurance from a publicly funded reinsurer (Caisse Centrale de Reassurance - $\mathrm{CCR}$ ). The French Government provides an unlimited guarantee to the CCR and hence meets claims that exceed the capital reserves of the CCR (Herweijer et al., 2009).

According to Fournier et al. (2018), traditionally, the French system focuses on prevention (from the definition set out by central government of land use planning restrictions and the identification of nonbuildable areas) and is implemented with the help of extensive legal instruments. The enforceability of such instruments is relatively high since the plans that prohibit development are legally binding (Larrue et al., 2016; Kaufmann and Wierieng, 2017). In 1995, a new system, the Fund for Major Natural Hazards (FMNH, also known as the "Barnier Fund") focused on strengthening prevention with the addition of new Flood Risk Prevention Plans called Plans de Prévention du Risque d'inondation (PPRi). The risk maps are now drafted by the government instead of municipalities, giving the central government the capacity to control building regulations at local level (Fournier et al., 2018). The PPRi are maps identifying areas exposed to a reference flood hazard (often the 100-year event) and include bans or restrictions on construction depending on the level of risk of an area (Barraqué and Moatty, 2020). In 2003, new instruments were developed for coordination and partnerships at the relevant level, such as the Plan of Action for Flood Prevention (Programme d'Action pour la Prévention des Inondations - PAPI, see Ministère de l'écologie, du développement durable, des transports et du logement, 2011), which had an objective of creating synergy and of coordinating actions and actors at the prevention level and at the risk basin-scale and to develop a multi-year strategy that relies on the implementation of the other existing public policy tools (Guillier, 2017). Concerning flood risk management, the PAPI is set around seven main lines of action: a) improving knowledge around flood risk, b) observation and prediction of flooding, c) flood alerts and crisis management, d) inclusion of flood risk in urban planning, e) vulnerability reduction, f) drainage management, and g) management of dikes and other flood protection structures. More recently, in 2014, a law focused on modernizing public action at local level (Modernisation de l'Action Publique Territoriale et d'Affirmation des Métropoles - MAPTAM) further strengthened the decentralization process while suggesting the transfer of Flood management power to the (inter)municipal bodies.

\subsection{French Flood Risk Governance system}

Integrated national approaches to flood risk management that strive to treat all aspects of the disaster cycle equally (i.e. risk prevention, emergency management and disaster recovery) are common around the world (e.g. Hall et al., 2005; Alexander et al., 2015; Mees et al., 2016). In Figure 1, we summarize the main elements of the integrated flood governance approach in France (e.g. Larrue et al., 2016; Ministère de la transition écologique, 2020). 
Each main element of the cycle contains multiple steps that are considered simultaneously. Specifically, risk prevention is characterised by an analysis of the hazard (i.e. a flood, or even knock-on effects, such as floods that cause landslides), the stakes and vulnerability of local stakeholders, as well as mitigation measures to be used in order to prevent a disaster. Emergency management contains emergency planning with scenario-making, response training of concerned teams (e.g. fire brigade, ambulance) and early warning systems such as flood depth alerts. Disaster recovery is characterised by the actions of the public solidarity system CatNat as described in Section 2.1 as well as private insurance companies and the newly added Build Back Better (BBB) culture, which was first officially used in the Sendai Framework (UNISDR, 2015) and focuses on improving land use, spatial planning, and construction standards through the recovery process (Noy et al., 2019).

Despite the resilient design of current French FRG, as it will be illustrated in Section 3 several deficiencies are observed when a flood disaster strikes. Therefore, to examine in detail these deficiencies, Section 3.3 provides an analysis of extreme flood events that took place in PACA; we focus on one of the deadliest recent events, that of October 2015, in order to observe the response of different actors before, during and after the disaster. This case study will conclude (Section 4) with a SWOT-analysis of the French FRG which will demonstrate the elements that we estimate need improvement.

\section{Extreme Flooding In Provence-alpes-côte D'Azur (Paca) 3.1 Study area and past flood disasters}

The PACA region in France is characterized by steep slopes and deep valleys, the coastal plains are surrounded by the Cévennes mountain range in the North West and the Alps in the East. Summer drought and intense Autumn rainfall are typical features of the climate (Petrucci et al., 2019). Rainfall is concentrated over the period September-December ( $50 \%$ of annual total). Winter is drier with cold, continental winds. Flash floods are common in the region (e.g. Vinet, 2008; Vinet et al., 2012; Heinzlef et al., 2019) with an important number of deadly historical events taking place since the creation of the CatNat national solidarity scheme in 1982. Some notable extreme flooding events that have provoked loss of life as well as significant material costs include the Vaison-la-Romaine floods (09/1992), the Draguignan floods (06/2010) and the most recent Côte d'Azur floods (10/2015). The region has also faced smaller flood events such as the Var and Alpes-Maritimes floods $(11 / 2011 ; 11-12 / 2019)$ and the Nice floods $(11 / 1994 ; 12 / 2005)$. According to Heinzlef et al. (2019), due to these issues, in the last 10 years, several PACA municipalities (e.g. Avignon) attempted to emphasize resilience in their urban planning.

\subsection{The October 2015 Côte d'Azur disaster}

According to the official document of the Préfet (Regional authority) des Alpes-Maritimes report (2016), on Saturday the $3^{\text {rd }}$ of October 2015 between 20:00 and 21:45 an exceptional rainfall event took place 
between Mandelieu-la-Napoule and Nice (for official rainfall maps see Météo-France[1]). This highly intense event, with approximately $200 \mathrm{~mm}$ of water in two hours is comparable to the 1966 catastrophic event that took place in the same region. According to Carrega (2016), these values correspond to a larger than a 100-year storm. More specifically, the Cannes Meteorological station recorded $175 \mathrm{~mm}$ of rainfall in two hours, which is approximately $80 \mathrm{~mm}$ more than the 100 -year event $(94,6 \mathrm{~mm})$. This exceptional rainfall caused a substantial increase in river discharge $\left(>250 \mathrm{~m}^{3} / \mathrm{s}\right.$, larger than the 100-year event as well), in the Argentière and the Brague rivers thereby reaching the levels of the 2010 flash flood that took place in the Var, also in southern France (Vinet et al., 2012). In addition, due to regionally steep slopes covered by Mediterranean vegetation, large, woody debris was swept into water courses, which dammed the main channels and caused water to be diverted onto floodplains. The Prefect of Alpes-Maritimes Region report (2016) declared that 20 people lost their lives during the event and that 1200 people were in need of immediate disaster relief measures.

\subsection{PACA flood risk governance deficiencies}

In the years following the October 2015 disaster, a number of reports were published (e.g. The Prefect of Alpes-Maritimes Region report, 2016; ARTELIA, 2017; CEREMA, 2019) that listed a number of pre-existing issues that might have led to the disaster such as a) inadequate land-use planning, b) inadequate prevention plans, $c$ ) inadequate warning systems in place, d) inadequate maximum threshold for emergency calls (only 20 calls simultaneously), e) lack of appropriate rain forecast modelling, f) lack of citizens' operational knowledge after an alert is initiated, and g) lack of road network mapping. These issues seem to be the same as the issues in past local disasters (listed in Section 3.1). In the following sub-sections (3.3.1 -3.3.3) we will briefly analyse all aspects of FRG in PACA (which follows the French governance system summarized in Figure 1) to observe, in detail, the pitfalls leading to repeated disasters.

\subsubsection{Risk prevention}

The current French FRG system is based on prevention (e.g. Kaufmann and Wiering, 2017; Fournier et al., 2018). The main goal is to reduce the exposure by the use of the legal instruments mentioned in Section 2 , such as the PPRi and the PAPI, and therefore the enforceability remains high. Nevertheless, it seems that these instruments had been significantly out-dated when the 2015 event took place (e.g. in Cannes the last PPRi was approved in 2003) and local population wasn't aware of this issue. This was also observed during the June 2010 Draguignan disaster, where $22 \%$ of residential buildings and approximately one in three employees were commuting into a flood risk zone for their work (INSEE, 2018).

Before 2010 flooding was considered to be a controllable natural phenomenon and the government was putting in place an important number of flood defences as part of those controls (Larrue et al., 2016; Kaufmann and Wiering, 2017). This trend is now changing, and the effectiveness of structural measures is recently questioned (Kaufmann and Wiering, 2017; Kron et al., 2019). During the October 2015 Côte 
d'Azur disaster, the artificial protection dikes were largely ineffective due to the severity of the phenomenon (with river discharges being larger than the 100-year event), while some dikes also trapped the large debris, thereby blocking the flow and worsening the situation (The Prefect of Alpes-Maritimes Region report, 2016). A similar phenomenon was observed in the September 1992 Vaison-la-Romaine disaster. According to Ballais and Segura (1995), the protection dikes and embankments which were put in place during the second world war to straighten the channel in the valley and provide space for construction, intensified runoff turbulence, and transported boulders and woody debris that blocked bridges and promoted damage downstream.

Moreover, flood mitigation measures such as retention ponds and wetland restoration are considered a viable option for flood management because they not only improve resilience directly by improving runoff management, but also indirectly through improving the legitimacy of the PAPI project, thereby illustrating the advantages of land-based flood control (Barraqué and Moatty, 2020). After the October 2015 event, PACA inhabitants were promised the construction of new retention ponds as well as the reinforcing of mitigation measures. In 2001, some years after the Vaison-la-Romaine and other flood disasters around France, the Assemblée Nationale (2001) published a document suggesting measures for regions facing repetitive flood disasters, such as in the PACA region. They underlined that the natural retention capacity has decreased due to the disappearance of wetlands which were often replaced by intensive agriculture, heavy infrastructure, and the extension of waterproof surfaces.

Another important prevention tool is the municipal information document on major risks (Document d'information communal sur les risques majeurs - DICRIM) which is designed to inform the local population of each municipality about existing risks and the different ways to protect against those risks. In short, the mayor is charged with informing the citizens exposed to major risks, and after that the government indicates the adequate protection measures and municipality safety plans, or Plans Communaux de Sauvegarde (PCS), in order to respond to a major disaster, if it occurs. The Prefect of Alpes-Maritimes Region report (2016) analysed 10 DICRIMs out of the 14 municipalities that suffered from the October 2015 PACA disaster (four did not have an available DICRIM). In three of these DICRIMs the mapping was inappropriate, with several locations missing per map and in all DICRIMs there was a lack of explanation of the particular characteristics of flash floods while the vulnerable locations were not clearly identified.

\subsubsection{Emergency management}

According to Vinet et al. (2012), when a natural disaster strikes it is most often the elderly that face difficulties dealing with early warnings or evacuation orders. During the October 2015 event, there was lack of information on flood risk as well as lack of preparedness to face catastrophic flooding, and no appropriate alert system in place. According to the Préfet des Alpes-Maritimes report (2016), the alert level, which functions with a colour coding (yellow-low risk, orange-medium risk and red-high risk), was misused. Météo-France triggered orange alerts on a regular basis since the creation of the system, which 
has the effect of normalising and trivialising the severity of the orange alert level. Furthermore, after observing the rainfall and discharge during the October 2015 event, the red alert signal should have been triggered which was not the case (the alert remained orange). Carrega (2016) underlines that inaccurate meteorological (rainfall) models forecasted only about $25 \%$ of the precipitation that occurred during the event thereby causing more confusion to the alert system. In addition, civilians apparently did not have sufficient knowledge of the alert protocol, which would allow an understanding of the alert messages, with many being confused on the colour coding. The French alert system (Flood vigilance - Vigicrues) also faced criticism during the June 2010 Draguignan disaster since the three main overflowing rivers causing significant damage to local communities were not monitored by the Vigicrues system (Sénat report, 2012).

Another important aspect that needs to be investigated relates to the emergency services training for flooding. According to Sénat (2012), the Prefect of Alpes-Maritimes Region (2016) and the CEREMA (2019) reports, which discuss the events presented in this paper (e.g. June 2010 Draguignan, October 2015 Côte d'Azur, November-December 2019 PACA), noticed that, despite the important number of firefighters involved and the declared emergency interventions (e.g. 1500 interventions and 600 fire-fighters involved in 2015), there were a lack of robust protocols for flood disasters. Apparently, local population, government and emergency services downplay flood risk (considering it medium risk) if compared to forest-fire risk, which leads to PCSs focused on the risk of wildfire rather than flooding. Consequently, the report from the Ministry of Environment (Ministère de l'environnement, de l'énergie et de la mer, 2016) suggested that, after the October 2015 event, a flood information and action week should take place, where all stakeholders could be involved (e.g. Météo-France, government, fire-fighters) and where all past events could be demonstrated. This type of yearly workshop already exists in wildfire and earthquake hazard prone areas in France, but not yet for floods.

\subsubsection{Disaster recovery}

Recovery in the French system is mainly based on insurance. Numerous authors have already pointed out some of the pitfalls of the current French flood insurance system and suggested a shift towards a new PPP mechanism offering more flexibility (e.g. Larrue et al., 2016; Kaufmann and Wiering, 2017; Fournier et al, 2018; Hudson et al., 2018; Kron et al., 2019; Barraqué and Moatty, 2020). The French solidarity insurance system, although very inclusive with more than $95 \%$ penetration seems to have played, unintendedly, a negative role in resilience, by blocking the possibility of a BBB culture (Barraqué and Moatty, 2020). In addition, according to Barraqué and Moatty (2020), the refunds received by the disaster victims cover the actual damages incurred, but numerous aspects, such as outdoor housing damages or non-monetary aspects (e.g. emotional impact), are not taken into account. According to the report from the Ministry of Environment (Ministère de la transition écologique, 2019), insurance companies refund on average 500 million euros for flood disasters, and the October 2015 event alone generated approximately 650 million euros of damage, which signals a heavy financial blow to insurance mechanism.

Furthermore, approximately 60,000 insurance claims were registered with $60 \%$ relating to housing 
damage, $30 \%$ to car and $10 \%$ to business. The extended impacts of this event led to a very high number of insurance claims, underlining the necessity for crisis units deployed in the field to deal directly with the claims as well as the increase in phone assistance capacity and the acceleration of refunds from the insurance companies.

\subsection{Persisting flood disasters after 2015}

After the October 2015 Côte d'Azur disaster discussed above, a number of preventive measures were put in place by the government (Table 1).

Despite persistent government efforts, the impacts of flood events in the region do not appear to have lessened over time, and heavy rainfall events continue to cause loss of life and to induce important material and immaterial damages at the same time. According to Météo-France[2], since the October 2015 event, 17 notable rainfall events took place in PACA up to January 2020 leading to 14 flood victims in total. Two recent events on 22-24/11/2019 and 01/12/2019 account for 11 of the victims and have also caused serious material damage. According to the French Insurance Federation (Fédération Française d' Assurance - FFA) [3], the costs of these two disasters total 390 million euros, while 57,000 insurance claims were registered ( $54 \%$ relating to housing damage, $12 \%$ to car and $34 \%$ to business).

Identical losses can be observed in the Riou de l'Argentière watershed. The stream that has burst its banks during the 2015 event did so again in 2019 causing damage to the same locations, while several protection dikes around the flooded area failed during these events, triggering local inhabitant protests in Mandelieu-la-Napoule as illustrated by the France 3 news channel on 01/12/2019[4] and on 06/09/2020[5]. In addition, the retention ponds promised after the 2015 disaster were still missing in various locations and are now estimated to start functioning in 2023 (see France-Digues on 09/12/2019[6]). Bokhove et al. (2019) conducted several workshops with local citizens in 2018 at the River Brague in Biot, and they illustrate that residents asked for more flood retention measures.

Furthermore, the CEREMA report (2019) illustrates that only $2 \%$ of the total population use the \#MyPredict app which alerts population against flooding, underlining the need for better communication on the side of flood governance.

More recently, in October 2020 (exactly five years after the October 2015 disaster) another major event took place. According to the FFA and CCR (2020) press release, after the 2020 catastrophic flooding event, 14,000 insurance claims were registered with a total cost of 210 million euros, again mostly damaging housing (72\%) compared to business (25\%) and car damages (3\%), and nine people lost their lives. The historical disaster analysis of the PACA region underlines the need for new policies to be put in place. As we observe in Le Moniteur (2020), the Architectural association of Côte d'Azur (Syndicat des architectes de la Côte d'Azur) are suggesting a new way of thinking linked to flooding risk starting with not rebuilding in the same locations again (or in the same manner) but rather adopt a BBB logic by strictly avoiding the areas identified as potentially flooded in the PPRi[7]. 


\section{Lessons For French Flood Risk Governance}

In this paper we illustrate, through a qualitative historical analysis of flood disasters in the PACA region, that the extent of flood damage in PACA has not decreased over time, and neither have disaster insurance claims. Furthermore, flood risk culture seems to be dealt with from the perspective of the individual and not on a collective municipality level. Finally, there has been no significant investment towards vulnerability reduction and resilience building (e.g. BBB programs, managed retreat). Following the case study, it is now timely to analyse in detail, the main strengths, weaknesses, opportunities, and threats that concern the French FRG system (Figure 2) in order to observe its pitfalls and suggest future improvements. To do so, we follow the methods used in similar past research (e.g. European STARFLOOD project), which provided SWOT-analysis for individual national FRG systems, such as the UK and Belgium (e.g. Alexander et al., 2015; Mees et al., 2016).

The first strength observed in the French system is the existence of an important number of prevention mechanisms and legal tools, such as the PPRi and the PAPI discussed extensively in the previous Sections $(2,3)$. This legal robustness is further underlined by constitutional principles of national solidarity to cope with disasters, and the image of the central state as the guardian of public safety, which is largely shared by the public (Fournier et al., 2018). For example, the hazard and vulnerability mapping provided by the PPRi is an important tool for decision makers and can also be easily accessible from the public in future decades with the help of technology such as mobile applications, etc. In addition, the combination of PPRi mapping and data as well as the information provided in aftermath of event reports can provide useful material for evaluating the efficiency of these instruments.

On the other hand, these well-defined prevention mechanisms possess a drawback since they need constant updating, which in some cases is not done on time due to lack of funds or personnel (e.g. after the 2015 disaster in Cannes it was found that the last PPRi was approved in 2003). For example, an important number of French pensioners choose to purchase housing and spend their retirement time in PACA without having previous knowledge of flood risk (and therefore they are more likely to overlook or be ignorant of the extent to which their house is in a high flood hazard zone). In order to optimise these prevention mechanisms in the future, decision makers will have to take into account the increasing concentration in urban centres as well as the impacts of climate change on hazard behaviour (e.g. flood frequency and severity).

The second strength of the French FRG is the significant insurance penetration rate (approximately 90\%) due to direct purchase requirement. This can be considered as welfare enhancing due to the improved financial coverage against disasters (e.g. Hudson et al., 2019). Furthermore, The Ministère de la transition écologique (2020) report announced that it will be reinforcing the role of the state in the CatNat insurance scheme by recentralizing financial activities and cancelling the management of these funds from the public reinsurer, Caisse Centrale de Réassurance. In addition, the report also underlines that complementary funding will be provided to tackle flooding (after the repeated disasters that took place in PACA in the last 10 years). Despite these important developments, the French solidarity insurance 
scheme seems to suffer from the following weaknesses: first, this current market structure may not be suitable for coping with future increases in flood risk due to insufficient incentives for risk reduction. By funding properties and locations that are damaged repeatedly by flooding, insurances do not assist in a BBB logic thereby limiting the capacity for resilience. As the EU Floods Directive (2007/60/EC) suggests, reducing flood risk by decreasing hazard, vulnerability and exposure must be the objective and, according to Kron et al. (2019), if insurance receives the residual risk which is difficult to control by means of structural and non-structural measures it can play the role of a lever for policy improvement.

Furthermore, in some cases victims of a severe climate related disaster do not even know if they are covered from the CatNat system as has been the case for agricultural producers experiencing heavy hailstorms (which are not covered by CatNat)[1]. In addition, in France, there is no empirical information on voluntary flood insurance purchases since the French solidarity framework is compulsory while risk estimation seems to be based only on declared damages, thereby limiting the capacity for risk reduction. Repetitive flood disasters due to climate change could lead to the dissolution of flood insurance which is the main threat for the future if the framework remains stagnant (Lamond and Penning-Rowsell, 2014). One common concern with widespread insurance is that it generates moral hazard, which might not be of significant concern for some hazards (e.g. earthquakes) where location predictions are not straightforward (Nguyen and Noy, 2019), but this might be the case for well delimited flood hazards where location predictions are easier to make (e.g. Lamond and Penning-Rowsell, 2014). Past research (e.g. Larrue et al., 2016; Kaufmann and Wiering, 2017; Fournier et al, 2018; Hudson et al., 2018; The Geneva Association, 2018; Kron et al., 2019; Barraqué and Moatty, 2020) points toward a more flexible system with increased PPP (keeping penetration rates as high as possible) and more funding towards vulnerability reduction and improving resilience through BBB.

The third strength of the system concerns the important level of specialization and know-how of the public services. France has a long tradition in hazard and vulnerability mapping as well as expert government engineering services (Larrue, et al., 2016; Fournier et al., 2018). France has a transparent system in that issues are clearly reported in government documents in the aftermath of events (e.g. Préfet des Alpes-Maritimes report, 2016), which are concise and distributed to the public domain. Nevertheless, the high degree of specialization is counter-balanced by a lack of synergy between actors and stakeholders of the three main elements of the FRG cycle (risk prevention, emergency management and disaster recovery). As an example, a lack of appropriate training and information for response teams on the ground is observed and emergency services, such as the firefighter services, are obliged to rely on protocols from other natural disasters (e.g. forest fires or earthquakes). Moreover, there is a lack of communication between the actors of the different steps (prepare, control, organise etc.) of the three main elements of the cycle (risk prevention, emergency management and disaster recovery). This is observed in numerous examples described in detail in Section 3.3, between meteorological (rainfall) model specialists and alert system experts, for example (Carrega, 2016); this has played a significant role in past major disasters globally. As Cyranoski (2011) underlines, during the Fukushima 2011 disaster, a warning system based on initial seismic signal predicted a limited region of intense shaking. The actual 
shaking was far more severe and widespread; therefore, the tsunami risk was heavily underestimated, and locals and emergency services did not react on maximum alert.

The fourth strength of the French FRG is the well-defined spatial scale (i.e. drainage basin) at which flood risk management is undertaken. This was implemented for the first time after 2007 in order to transpose the EU Floods Directive into French law (Larrue et al., 2016). The study of flood risk by drainage basin brings some important benefits, especially for the analysis of flood hazard, since rapid accumulation of runoff (occurring from heavy storms) can be controlled in the upstream parts of the catchment (e.g. riparian zone management). In addition, wetland areas within the basin can be studied and preserved as non-structural measures against flooding. With that in mind, French river contracts (Gestion des milieux aquatiques et de prévention des inondations - GEMAPI) were created. These bring together various partners (Prefect of the department, water agencies and other local authorities) focusing on a set of common goals ranging from: management of water quality, enhancement of the aquatic environment and water resources, as well as defending against flooding. Furthermore, the PAPI are also designed on a drainage basin scale and they must combine measures and suggestions on knowledge improvement, monitoring and forecasting, information, planning, protection works, reduction of vulnerability (of buildings), crisis management preparedness and feedback on operations (Larrue et al., 2016). Studying floods on a drainage basin scale offers future opportunities for the French FRG including the potential to monitor the effects of the existing prevention approaches in a regional or municipal scale. Nevertheless, the drainage basin scale also presents several weaknesses. First, it is not easily understood by nonexperts and second, it provides a false perception that risk is limited to flood hazard areas thereby limiting the capacity to reduce vulnerability in areas that might suffer indirectly from flooding issues (e.g. a municipality situated outside of flooding area, many of whose residents may work in flood prone areas and therefore suffer indirect economic impacts). Since 1982, a decentralisation process was initiated leading to a transfer of responsibilities from the central government towards local authorities (Kaufmann and Wiering, 2019) aiming to create command and response units for flood disasters on a local level and adapted to the different types of flooding (e.g. Mediterranean flash floods, Northern France fluvial floods). This decentralisation can cause important public funding disparities between municipalities. For example, after repeated flooding $(2015,2019,2020)$ in the Riou de l'Argentière watershed, the local government has not focused on improving resilience or allocated any funding for the relocation of constantly damaged elements whereas, as Heinzlef et al. (2019) indicate, the authorities of the city of Avignon have demanded for increased resilience planning for frequently flooded areas and has placed the city under a pilot study.

The fifth strength that we identified in the French FRG system is that an important number of government services participate in shaping flood governance protocols. As Kaufmann and Wiering (2017) explain, managing flood risk is conceived to be a collective task. Fournier et al. (2018) illustrate in depth the numerous instruments and institutions that participate in tackling flooding in the country (e.g. CEREMA, DREAL, local prefecture experts, ministries) meaning that a large number of specialists are focused on preventing flood disasters and alerting local population. This is also evident in the large amount of research programs and funding directed towards flood governance and flood hazard and risk modelling 
(e.g. Vinet et al., 2012; Boudou et al., 2016; Larrue et al., 2016; Montanéet al., 2017; Fournier et al., 2018; Lieffernik et al., 2018; Barraqué and Moatty, 2020; Fournier, 2020). Another opportunity concerning the participation of government services in flood governance protocols is the application of corrective measures (see Table 1 after October 2015 disaster in PACA) and the desire to improve the system as evident in the transparent official event aftermath documents placed in the public domain (e.g. Prefect of Alpes-Maritimes Region report, 2016). Nevertheless, due to a "state covers all" logic, participation from local population is minimal which does not help in improving resilience. For example, only one flood awareness day per year was planned in PACA after the October 2015 disaster. Ideally region-wide workshops should take place considering all three elements of the cycle (risk prevention, emergency management and disaster recovery) and explanatory flyers should be tailored to the needs of each municipality to shape the local population's perception of risk, which is another threat for the French FRG system. According to the IRSN (2020), despite the alarming impacts of climate change in flood frequency and severity the perception of the French population towards flood risk has not changed much since 1997. Throughout the years, around $40 \%$ consider the risk to be high, $40 \%$ consider it to be medium, and $20 \%$ consider it to be low. In addition, even though flooding has been by far the costliest natural disaster in France, the population feels confident that state services are protecting them more than is the case for other risks (e.g. pesticides, terrorism, air-water-soil pollution).

In this paper we illustrate the complexities of the French FRG following a historical investigation of PACA floods as well as an in -depth SWOT-analysis. Future studies could use operational research methods to model the governance system and the resilience of each municipality and to provide a Decision Support System (DSS) which can be rapidly adapted to each different region and hazard in France by inputting the appropriate data in the defined parameters. To do so, Multi-Criteria Decision Analysis (MCDA) can be employed as has been undertaken already in several other contexts, such as health insurance policies (Marsh et al., 2018; Anzilli and Give, 2020) and climate change risk assessment (hazard and vulnerability) (e.g. Merad et al., 2004; Kougkoulos et al., 2018). MCDA is recognized as an important method in decision-making for formalizing and addressing problems with competing decision objectives, such as is the case for flood risk management. The first step of the MCDA would consist in reviewing all criteria (e.g. qualitative and quantitative) that could be used to assess the resilience of different municipalities hit by repetitive flood disasters in France. These could range from, preventive measures (e.g. PPRI, DICRIM) and losses (e.g. costs for individuals, fatalities) to vulnerability (e.g. population density, ageing index) and response of each municipality after the disaster. Next, the aggregation procedure used (e.g. outranking) will depend upon the uncertainty of the data. In conclusion, once the resilience of each municipality is evaluated with the help of the tool, the results could be presented to the government and local municipalities with detailed mapping.

\section{Conclusion}

In this paper, we perform, for the first time, an in-depth analysis of the French FRG system (Figure 1). To do so, we focus on a specific region (PACA) and employ a historical assessment of catastrophic past flood events combined with a SWOT-analysis of the system. Our analysis shows despite the application 
of costly new structural and non-structural measures from the government (after the October 2015 disaster), the impacts of flood events in the region do not appear to have lessened over time and consecutive events have led to 23 more flood victims in total. Since flood hazard is predicted to intensify due to climate change, the situation demands for improvements in the French FRG approach to avoid further major disasters. The key findings of this paper illustrate that, despite its numerous strengths, the French FRG can benefit from several improvements. Notably these include: a) regular updates of the risk prevention plans and tools (e.g. PPRI, PAPI); b) the adoption of a BBB logic instead of promoting the reconstruction of damaged elements in the same locations; $c$ ) taking into account undeclared damages into flood risk models (and not only those declared to flood insurance); d) increased communication between the actors of the different steps of each cycle (prepare, control, organise etc.); e) increased communication between three main elements of the cycle (risk prevention, emergency management and disaster recovery); f) an approach that extends the risk analysis outside the borders of the drainage basin (to be used in combination with the current basin risk models); and g) increased participation in FRG from local population. In addition, we suggest that future research should focus on the development of operational research methods (e.g. MCDA) in order to create models that will perform in multiple geographical settings (e.g. different climates, different types of flooding) and multiple scales (e.g. regional, national).

\section{Declarations}

\section{Acknowledgements}

This work is funded by the European Commission (DG ECHO - Directorate General for European Civil protection and Humanitarian Aid Operations) under the LODE (Loss Data Enhancement for DRR and CCA Management) project. 


\section{Funding}

This work is funded by the European Commission (DG ECHO - Directorate General for European Civil protection and Humanitarian Aid Operations) under the LODE (Loss Data Enhancement for DRR and CCA Management) project (826567).

Conflicts of interest/Competing interests

The authors declare that there is no conflict of interest

\section{Availability of data Not applicable and material}

Code availability Not applicable

Authors' contributions
We followed the CRediT (Contributor Roles Taxonomy) author statement to clarify the contribution of each author:

loannis Kougkoulos: Conceptualization, Methodology, Formal analysis, Investigation, Writing - Original Draft, Writing - Review \& Editing, Visualization.

Myriam Merad: Conceptualization, Methodology, Writing - Review \& Editing, Project administration, Funding acquisition.

Simon J. Cook: Conceptualization, Writing - Review \& Editing.

Ioannis Andredakis: Conceptualization, Writing - Review \& Editing

\section{References}

1. Aerts JCJH, Botzen WJ, Clarke KC, et al (2018) Integrating human behaviour dynamics into flood disaster risk assessment. Nat Clim Chang 8:193-199. https://doi.org/10.1038/s41558-018-0085-1

2. Anzilli L, Giove S (2020) Multi-criteria and medical diagnosis for application to health insurance systems: a general approach through non-additive measures. Decis Econ Financ. https://doi.org/10.1007/s10203-020-00302-x

3. ARTELIA. 2017. Étude de la problématique inondation des vallons des Combes et de Sainte-Colombe : diagnostic des réseaux pluviaux et propositions d'aménagement. Métropole Nice Cote d'Azur, Direction de l'Eau, de l'Air et de la Qualité des Milieux, Service Assainissement - Pôle Hydraulique et Pluvial. https://www.alpesmaritimes.gouv.fr/content/download/31411/247873/file/6.Rapport_Combes_VF.pdf

4. Assemblée Nationale. 2001. Rapport fait au nom de la commission d'enquête sur les causes des inondations répétitives ou exceptionnelles et sur les conséquences des intempéries afin d'établir les responsabilités, d'évaluer les coûts ainsi que la pertinence des outils de prévention, d'alerte et d'indemnisation. http://www.assemblee-nationale.fr/rap-enq/r3386-01.asp

5. Ballais J, Ségura P (1995) La catastrophe de Vaison- la-Romaine (22 septembre 1992): une inondation dans un géosystème anthropisé. In: 120ème Congrès national des Sociétés historiques et scientifiques. 1-48. 
6. Barraqué B, Moatty A (2020) The French Cat' Nat' system: post-flood recovery and resilience issues. Environ Hazards 19:285-300. https://doi.org/10.1080/17477891.2019.1696738

7. Bokhove O, Kelmanson MA, Kent T, et al (2019) Communicating (nature-based) flood-mitigation schemes using flood-excess volume. River Res Appl 35:1402-1414. https://doi.org/10.1002/rra.3507

8. Boudou M, Lang M, Vinet F, Cœur D (2016) Comparative hazard analysis of processes leading to remarkable flash floods (France, 1930-1999). J Hydrol 541:533-552. https://doi.org/10.1016/j.jhydrol.2016.05.032

9. Bouwer LM (2011) Have disaster losses increased due to anthropogenic climate change? Bull Am Meteorol Soc 92:39-46. https://doi.org/10.1175/2010BAMS3092.1

10. Carrega $P$ (2016) Les inondations azuréennes du 3 octobre 2015: un lourd bilan lié à un risque composite. Pollut atmosphérique 1-26. https://doi.org/10.4267/pollution-atmospherique.5475

11. CEREMA. 2019. Perception du risque inondation, Analyse d'expériences et recommandations pour mener une enquête auprès des populations. http://www.paca.developpementdurable.gouv.fr/IMG/pdf/rapport_enquete_perception_risque_inondation_arc_med.pdf

12. Clemo K (2008) Preparing for climate change: Insurance and small business. Geneva Pap Risk Insur Issues Pract 33:110-116. https://doi.org/10.1057/palgrave.gpp.2510160

13. Coumou D, Rahmstorf S (2012) A decade of weather extremes. Nat Clim Chang 2:491-496. https://doi.org/10.1038/nclimate1452

14. Creach A, Bastidas-Arteaga E, Pardo S, Mercier D (2020) Vulnerability and costs of adaptation strategies for housing subjected to flood risks: Application to La Guérinière France. Mar Policy 117:103438. https://doi.org/10.1016/j.marpol.2019.02.010

15. CRED-UNISDR, 2015. The Human Cost of Weather Related Disasters, 1995-2015. Centre for Research on the Epidemiology of Disasters and United Nations Office for Disaster Risk Reduction.

16. Cremades R, Surminski S, Máñez Costa M, et al (2018) Using the adaptive cycle in climate-risk insurance to design resilient futures. Nat Clim Chang 8:4-7. https://doi.org/10.1038/s41558-0170044-2

17. Crichton D (2008) Role of insurance in reducing flood risk. Geneva Pap Risk Insur Issues Pract 33:117-132. https://doi.org/10.1057/palgrave.gpp.2510151

18. Cyranoski D (2011) Japan faces up to failure of its earthquake preparations. Nature 471:556-557. https://doi.org/10.1038/471556a

19. Dixit A (2003) Floods and vulnerability: Need to rethink flood management. Nat Hazards 28:155179. https://doi.org/10.1023/A:1021134218121

20. EU, 2007. Directive 2007/60/EC of the European Parliament and of the Council of 23 October 2007 on the assessment and management of flood risks. Off. J. Eur. Union L288, 27-34.

21. Evin G, Wilhelm B, Jenny JP (2019) Flood hazard assessment of the Rhône River revisited with reconstructed discharges from lake sediments. Glob Planet Change 172:114-123. 
https://doi.org/10.1016/j.gloplacha.2018.09.010

22. Fournier M, Larrue $C$, Schellenberger $T$ (2018) Changes in flood risk governance in France: a David and Goliath story? J Flood Risk Manag 11:261-270. https://doi.org/10.1111/jfr3.12314

23. Fournier M (2020) Flood Governance in France: From Hegemony to Diversity in the French Flood-Risk Management Actors' Network. In: Isabelle La Jeunesse, Larrue C (eds) Facing Hydrometeorological Extreme Events: A Governance Issue, First Edit. John Wiley \& Sons Ltd., pp. 125-139.

24. FFA and CCR. 2020. Inondations dans les Alpes-Maritimes 14000 sinistres estimés pour un coût évalué à 210 millions d'euros. https://catastrophes-naturelles.ccr.fr/-/inondations-dans-les-alpesmaritimes

25. Gallagher J (2014) Learning about an infrequent event: Evidence from flood insurance take-up in the United States. Am Econ J Appl Econ 6:206-233. https://doi.org/10.1257/app.6.3.206

26. Guillier F (2017) French Insurance and Flood Risk: Assessing the Impact of Prevention Through the Rating of Action Programs for Flood Prevention. Int J Disaster Risk Sci 8:284-295. https://doi.org/10.1007/s13753-017-0140-y

27. Hall JW, Sayers PB, Dawson RJ (2005) National-scale assessment of current and future flood risk in England and Wales. Nat Hazards 36:147-164. https://doi.org/10.1007/s11069-004-4546-7

28. Hallegatte S, Green C, Nicholls RJ, Corfee-Morlot J (2013) Future flood losses in major coastal cities. Nat Clim Chang 3:802-806. https://doi.org/10.1038/nclimate1979

29. Heinzlef C, Becue V, Serre D (2019) Operationalizing urban resilience to floods in embanked territories - Application in Avignon, Provence Alpes Côte d'azur region. Saf Sci 118:181-193. https://doi.org/10.1016/j.ssci.2019.05.003

30. Herweijer C, Ranger N, Ward RET (2009) Adaptation to climate change: Threats and opportunities for the insurance industry. Geneva Pap Risk Insur Issues Pract 34:360-380. https://doi.org/10.1057/gpp.2009.13

31. Hudson P, Botzen WJW, Aerts JCJH (2019) Flood insurance arrangements in the European Union for future flood risk under climate and socioeconomic change. Glob Environ Chang 58:101966. https://doi.org/10.1016/j.gloenvcha.2019.101966

32. IPCC. 2018. Global Warming of 1.5C. IPCC, Switzerland.

33. INSEE. 2018. Un million d'habitants vivent en zone inondable. https://www.insee.fr/fr/statistiques/3614748\#consulter

34. IRSN. 2020. Baromètre 2020 : La perception des risques et de la sécurité par les français. https://www.irsn.fr/FR/IRSN/Publications/barometre/Documents/IRSN_Barometre_2020graphiques.pdf

35. Jongman B (2018) Effective adaptation to rising flood risk. Nat Commun 9:9-11. https://doi.org/10.1038/s41467-018-04396-1

36. Kaufmann M, Wiering M (2017) Discursive junctions in flood risk governance - A comparative understanding in six European countries. J Environ Manage 196:376-386. 
https://doi.org/10.1016/j.jenvman.2017.03.012

37. Koc K, Işık Z (2020) A multi-agent-based model for sustainable governance of urban flood risk mitigation measures. Nat Hazards 104:1079-1110. https://doi.org/10.1007/s11069-020-04205-3

38. Kougkoulos I, Cook SJ, Jomelli V, et al (2018) Use of multi-criteria decision analysis to identify potentially dangerous glacial lakes. Sci Total Environ 621:1453-1466.

https://doi.org/10.1016/j.scitotenv.2017.10.083

39. Kousky C (2018) Financing Flood Losses: A Discussion of the National Flood Insurance Program. Risk Manag Insur Rev 21:11-32. https://doi.org/10.1111/rmir.12090

40. Kousky C, Cooke R (2012) Explaining the failure to insure catastrophic risks. Geneva Pap Risk Insur Issues Pract 37:206-227. https://doi.org/10.1057/gpp.2012.14

41. Kron W, Eichner J, Kundzewicz ZW (2019) Reduction of flood risk in Europe - Reflections from a reinsurance perspective. J Hydrol 576:197-209. https://doi.org/10.1016/j.jhydrol.2019.06.050

42. Kunreuther $\mathrm{H}$ (2015) The Role of Insurance in Reducing Losses from Extreme Events: The Need for Public-Private Partnerships. Geneva Pap Risk Insur Issues Pract 40:741-762. https://doi.org/10.1057/gpp.2015.14

43. Lamond JE, Bhattacharya-Mis N, Chan FKS, et al (2019) Flood risk insurance, mitigation and commercial property valuation. Prop Manag 37:512-528. https://doi.org/10.1108/PM-11-2018-0058

44. Lamond J, Penning-Rowsell E (2014) The robustness of flood insurance regimes given changing risk resulting from climate change. Clim Risk Manag 2:1-10. https://doi.org/10.1016/j.crm.2014.03.001

45. Larrue C, Bruzzone S, Lévy L, et al (2016) Analysing and evaluating flood risk governance in France. From state policy to local strategies

46. Le Coz J, Patalano A, Collins D, et al (2016) Crowdsourced data for flood hydrology: Feedback from recent citizen science projects in Argentina, France and New Zealand. J Hydrol 541:766-777. https://doi.org/10.1016/j.jhydrol.2016.07.036

47. Lenderink G, Van Meijgaard E (2008) Increase in hourly precipitation extremes beyond expectations from temperature changes. Nat Geosci 1:511-514. https://doi.org/10.1038/ngeo262

48. Liefferink D, Wiering M, Crabbé A, Hegger D (2018) Explaining stability and change. Comparing flood risk governance in Belgium, France, the Netherlands, and Poland. J Flood Risk Manag 11:281-290. https://doi.org/10.1111/jfr3.12325

49. Luke A, Sanders BF, Goodrich KA, et al (2018) Going beyond the flood insurance rate map: Insights from flood hazard map co-production. Nat Hazards Earth Syst Sci 18:1097-1120. https://doi.org/10.5194/nhess-18-1097-2018

50. Lumbroso D, Stone K, Vinet F (2011) An assessment of flood emergency plans in England and Wales, France and the Netherlands. Nat Hazards 58:341-363. https://doi.org/10.1007/s11069-010-9671-x

51. Magnan S (1995) Catastrophe Insurance System in France. Geneva Pap Risk Insur - Issues Pract 20:474-480. https://doi.org/10.1057/gpp.1995.42 
52. Marsh K, Thokala P, Youngkong S, Chalkidou K (2018) Incorporating MCDA into HTA: Challenges and potential solutions, with a focus on lower income settings. Cost Eff Resour Alloc 16:1-9. https://doi.org/10.1186/s12962-018-0125-8

53. Mees H, Suykens C, Beyers J-C, et al (2016) Analysing and evaluating flood risk governance in Belgium. Dealing with flood risks in an urbanised and institutionally complex country.

54. Merad MM, Verdel T, Roy B, Kouniali S (2004) Use of multi-criteria decision-aids for risk zoning and management of large area subjected to mining-induced hazards. Tunn Undergr Sp Technol 19:125138. https://doi.org/10.1016/S0886-7798(03)00106-8

55. Miller JD, Hutchins M (2017) The impacts of urbanisation and climate change on urban flooding and urban water quality: A review of the evidence concerning the United Kingdom. J Hydrol Reg Stud 12:345-362. https://doi.org/10.1016/j.ejrh.2017.06.006

56. Ministère de la transition écologique. 2020. Prévention des inondations. https://www.ecologie.gouv.fr/prevention-des-inondations

57. Ministère de la transition écologique. 2019. Guide méthodologique "APRÈS inondation" Organisation de la collecte des données issues des REX inondation. Proposé par le rapport n 012486-01. " Organisation de la collecte des données issues des REX inondations ». https://www.cerema.fr/system/files/documents/2019/09/012486-01_guidemethodologique_cle7b1338.pdf

58. Ministère de l'écologie, du développement durable, des transports et du logement, 2011. Programmes d'action de prévention des inondations (PAPI) (Paris). https://www.cepri.net/tl_files/pdf/appelprojetspapi3.pdf

59. Ministère de l'environnement, de l'énergie et de la mer. 2016. Propositions d'actions pour mieux gérer les inondations en zone méditerranéenne et limiter leurs conséquences. Propositions d'actions pour mieux gérer les inondations en zone méditerranéenne et limiter leurs conséquences. Rapport $\mathrm{n}^{\circ}$ 010664-01. https://www.vie-publique.fr/sites/default/files/rapport/pdf/174000015.pdf

60. Montané A, Buffin-Bélanger T, Vinet F, Vento O (2017) Mappings extreme floods with numerical floodplain models (NFM) in France. Appl Geogr 80:15-22. https://doi.org/10.1016/j.apgeog.2017.01.002

61. NatCatSERVICE. 2017. Data on natural disasters since 1980. Munich Re. https://www.munichre.com/en/solutions/for-industry-clients/natcatservice.html

62. Nguyen CN, Noy I (2020) Comparing earthquake insurance programmes: how would Japan and California have fared after the 2010-11 earthquakes in New Zealand? Disasters 44:367-389. https://doi.org/10.1111/disa.12371

63. Noy I, Ferrarini B, Park D (2019) Build Back Better Adb Economics. Asian Dev Bank Econ Work Pap Ser

64. Paprotny D, Sebastian A, Morales-Nápoles O, Jonkman SN (2018) Trends in flood losses in Europe over the past 150 years. Nat Commun 9:. https://doi.org/10.1038/s41467-018-04253-1 
65. Paudel Y (2012) A Comparative study of public-private catastrophe insurance systems: Lessons from current practices. Geneva Pap Risk Insur Issues Pract 37:257-285. https://doi.org/10.1057/gpp.2012.16

66. Petrucci O, Aceto L, Bianchi C, et al (2019) Flood Fatalities in Europe, 1980-2018: Variability, Features, and Lessons to Learn. Water 11:28. https://doi.org/doi:10.3390/w11081682

67. Préfet des Alpes-Maritimes report. 2016. Inondations des 3 et 4 octobre 2015 dans les AlpesMaritimes : retour d'expérience.

68. Reynaud A, Aubert C (2020) Does flood experience modify risk preferences? Evidence from an artefactual field experiment in Vietnam. Palgrave Macmillan UK. https://doi.org/10.1057/s10713019-00044-w.

69. Roder G, Hudson P, Tarolli P (2019) Flood risk perceptions and the willingness to pay for flood insurance in the Veneto region of Italy. Int J Disaster Risk Reduct 37:101172. https://doi.org/10.1016/j.ijdrr.2019.101172

70. Roudier P, Andersson JCM, Donnelly C, et al (2016) Projections of future floods and hydrological droughts in Europe under a $+2^{\circ} \mathrm{C}$ global warming. Clim Change 135:341-355. https://doi.org/10.1007/s10584-015-1570-4

71. Schwarze R, Wagner GG (2004) In the Aftermath of Dresden: New Directions in German Flood Insurance. Geneva Pap Risk Insur Issues Pract 29:154-168. https://doi.org/10.1111/j.14680440.2004.00279.x

72. Scolobig A, Komendantova N, Patt A, et al (2014) Multi-risk governance for natural hazards in Naples and Guadeloupe. Nat Hazards 73:1523-1545. https://doi.org/10.1007/s11069-014-1152-1

73. Sénat. 2012. Rapport d'information fait au nom de la mission commune d'information sur les inondations qui se sont produites dans le var, et plus largement, dans le sud-est de la France au mois de novembre 2011. Session extraordinaire de 2011-2012. № 775. https://www.senat.fr/rap/r11775/r11-7751.pdf

74. Singkran N, Kandasamy J (2016) Developing a strategic flood risk management framework for Bangkok, Thailand. Nat Hazards 84:933-957. https://doi.org/10.1007/s11069-016-2467-x

75. Surminski S, Aerts JCJH, Botzen WJW, et al (2015) Reflections on the current debate on how to link flood insurance and disaster risk reduction in the European Union. Nat Hazards 79:1451-1479. https://doi.org/10.1007/s11069-015-1832-5

76. Surminski S, Hudson $P$ (2017) Investigating the risk reduction potential of disaster insurance across Europe. Geneva Pap Risk Insur Issues Pract 42:247-274. https://doi.org/10.1057/s41288-016-00397

77. Swiss Re. 2014. Mind the risk: a global ranking of cities under threat from natural disasters.

78. The Geneva Association. 2018. Climate Change and the Insurance Industry: Taking Action as Risk Managers and Investors. Perspectives from C-level executives in the insurance industry. https://www.genevaassociation.org/sites/default/files/research-topics-document- 
type/pdf_public/climate_change_and_the_insurance_industry__taking_action_as_risk_managers_and_investors.pdf

79. Tullos D, Byron E, Galloway G, et al (2016) Review of challenges of and practices for sustainable management of mountain flood hazards. Nat Hazards 83:1763-1797. https://doi.org/10.1007/s11069-016-2400-3

80. Turner G, Said F, Afzal U (2014) Microinsurance demand after a rare flood event: Evidence from a field experiment in Pakistan. Geneva Pap Risk Insur Issues Pract 39:201-223. https://doi.org/10.1057/gpp.2014.8

81. UNISDR (United Nations International Strategy for Disaster Reduction). 2015. Sendai framework for disaster risk reduction 2015-2030. http://www.wcdrr.org/uploads/Sendai_Framework_for_Disaster_Risk_Reduction_2015-2030.pdf.

82. Vedeld T, Coly A, Ndour NM, Hellevik S (2016) Climate adaptation at what scale? Multi-level governance, resilience, and coproduction in Saint Louis, Senegal. Nat Hazards 82:173-199. https://doi.org/10.1007/s11069-015-1875-7

83. Vinet $F$, Lumbroso D, Defossez S, Boissier L (2012) A comparative analysis of the loss of life during two recent floods in France: The sea surge caused by the storm Xynthia and the flash flood in Var. Nat Hazards 61:1179-1201. https://doi.org/10.1007/s11069-011-9975-5

84. Vinet $F$ (2008) Geographical analysis of damage due to flash floods in southern France: The cases of 12-13 November 1999 and 8-9 September 2002. Appl Geogr 28:323-336. https://doi.org/10.1016/j.apgeog.2008.02.007

85. Wing OEJ, Pinter N, Bates PD, Kousky C (2020) New insights into US flood vulnerability revealed from flood insurance big data. Nat Commun 11:1-10. https://doi.org/10.1038/s41467-020-15264-2

86. Winsemius HC, Aerts JCJH, Van Beek LPH, et al (2016) Global drivers of future river flood risk. Nat Clim Chang 6:381-385. https://doi.org/10.1038/nclimate2893

87. Zhang W, Villarini G, Vecchi GA, Smith JA (2018) Urbanization exacerbated the rainfall and flooding caused by hurricane Harvey in Houston. Nature 563:384-388. https://doi.org/10.1038/s41586-0180676-z

\section{Tables}

Table 1. List of improvements on preventive measures put in place in affected areas after the October 2015 disaster 
Structural

measures
Several rehabilitation works around the area including the creation of a hydraulic model and the stabilization of riversides.

- Dam repairs: waterproofing renovated, cracking indicators installed, and damaged structures repaired.

Addition of flood defences in several municipal buildings.

Alert system

Improvement of the alert system making it capable of receiving more than 1400 emergency calls.

Information, training and stakeholders

Open tools and applications

Distribution of 2000 flyers in the riskiest areas of the municipality.

A yearly flood awareness day.

Creation of a mobile App (\#MyPredict) for the estimation of risk from weather forecast and the management of flood warnings.

Purchase of 3D mapping tools and satellite phones from municipalities.

General administrative measures
Removal of 50 tons of natural and anthropogenic waste from the valley and waterways and approximately $400000 \mathrm{~m}^{2}$ of riverbanks cleaned.

Revision of the PPRi adding three hazard zones.

Creation of 9 new PAPI projects.

\section{Figures}




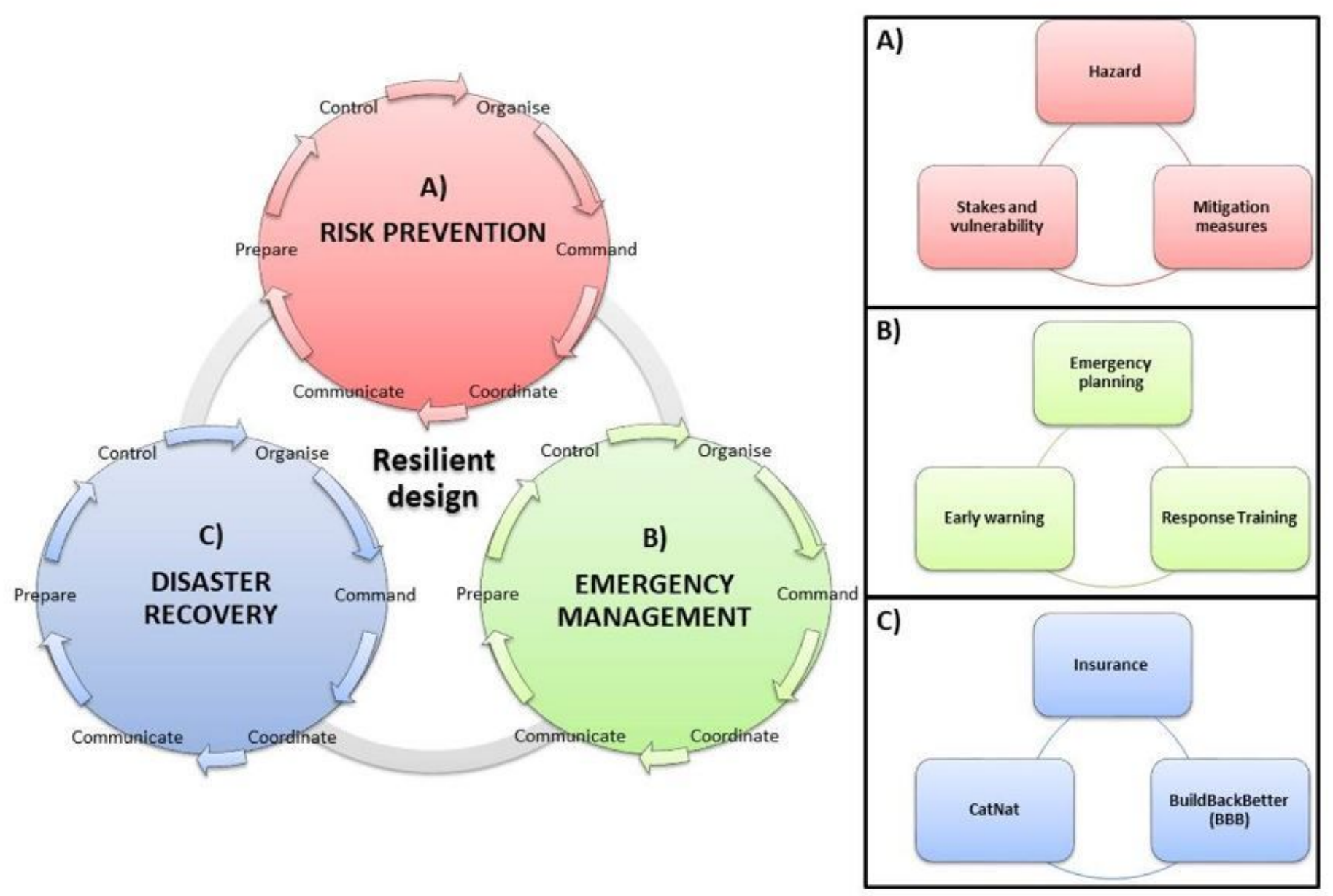

Figure 1

French Flood Risk Governance (FRG) system 


\section{INTERNAL FACTORS}

\section{STRENGTHS (+)}

- S1. Important number of robust risk prevention mechanisms (e.g. PPRi, PAPI)

- S2. Very high insurance penetration rate (approximately $100 \%$

- S3. Significant know-how of the prevention specialists (e.g. mapping, technical and engineering services)

- $\$ 4$. Well defined flood management scale (i.e. drainage basin)

- S5. Participation in regulatory protocols from an important number of government services
W1. Due to their important number risk prevention tools are, in some cases, not updated regularly

- W2.1. Insurance funding reconstruction of damaged elements in same locations instead of using a Build Back Better logic

- W2.2. Risk is only based on declared damages thereby limiting the capacity for risk reduction

- W3.1. Lack of synergy between the three main elements of the cycle (Figure 1 A, B, C)

- W3.2. Lack of communication between different steps of each element (prepare, control, organise etc.)

- W4.1. Drainage basin scale not easily understood by non experts

- W4.2. Drainage basin scale giving a false idea that risk is limited on flood hazard areas

- W5. Lack of participation from local population

\section{\begin{tabular}{|l|l}
\hline & EXTERNAL \\
\hline OPPORTUNITIES $(+)$ & \\
\hline
\end{tabular}}

- O1. Prevention mechanism easily evaluated due to the existence of long-term data

- O2.1. Government reforms to recentralize accounting and financial management

- O2.2. Increase of funding for flood insurance

- O3.1. Flood Risk Governance issues clearly reported in official government aftermath of events documents

- O3.2. Acknowledgement of fragmentation and lack of synergy issues in the flood governance system from the government

- O4. Capacity to monitor the effect of prevention approaches in the regional and municipal scale

- O5.1. Important number of research programs focusing on flood risk governance, flood hazard, flood modelling etc.

- O5.2. Application of corrective measures (See Table 1 - List of improvements after October 2015)
- T1.1. Increasing urban concentration

- T1.2. Impact of climate change on flood frequency and severity

- T2. Repetitive flood damage due to climate change could cause insurance cancellation

T3. Decreasing public subsidies causing issues in flood risk prevention

T4. Decentralization causing public funding disparities

- T5. Gap between specialists' idea of a major risk and the perception of risk from the public

\section{Figure 2}

\section{SWOT-analysis of the French FRG.}

